\title{
Kinetics study of CWPO of phenol wastewater over Cu-ZSM-5/PSSF catalysts prepared by ion-exchanged method
}

\author{
Yanjie $\mathrm{Wu}^{1}$, Huiping Zhang ${ }^{2}$, and Ying $\mathrm{Yan}^{3}$ \\ ${ }^{1}$ South China University of Technology \\ ${ }^{2}$ Affiliation not available \\ ${ }^{3}$ south china university of technology
}

May 26, 2021

\begin{abstract}
Cu-ZSM-5 was prepared on the paper-like sintered stainless steel fibers (PSSF) by ion-exchange method for catalytic wet peroxide oxidation (CWPO) of phenol in a fixed bed reactor. The prepared Cu-ZSM-5/PSSF catalyst was characterized by SEM, BET, XRD, FT-IR and UV-vis, respectively. And the effects of different catalyst bed height, reaction temperature and feed flow rate on catalytic performance were investigated to obtain optimum reaction condition. Finally, the catalytic reaction kinetics analysis over Cu-ZSM-5/PSSF catalyst were carried out with the Power-rate Law Kinetic model. The experimental results showed that the reaction order was the first-order reaction, and the activation energy of the oxidation reaction was $\mathrm{Ea}=72.9 \mathrm{~kJ} / \mathrm{mol}$. The initial oxidation rate equation (-rA0=5.36 $\times 108$ e-72994/RT CA) was obtained for phenol degradation using $\mathrm{Cu}-\mathrm{ZSM}-5 /$ PSSF catalyst.
\end{abstract}

\section{Hosted file}

Manuscript .doc available at https : //authorea.com/users/415982/articles/523717-kinetics-studyof-cwpo-of-phenol-wastewater-over-cu-zsm-5-pssf-catalysts-prepared-by-ion-exchangedmethod

\section{Hosted file}

Highlights.docx available at https://authorea.com/users/415982/articles/523717-kineticsstudy-of-cwpo-of-phenol-wastewater-over-cu-zsm-5-pssf-catalysts-prepared-by-ionexchanged-method

\section{Hosted file}

Graphical abstract.docx available at https://authorea.com/users/415982/articles/523717kinetics-study-of-cwpo-of-phenol-wastewater-over-cu-zsm-5-pssf-catalysts-prepared-byion-exchanged-method 